\title{
Non -verbal Politeness in English Etiquette Books and Prophetic Sunnah
}

\author{
Muhammed Badea' Ahmed, Ayhan Abdul Mun'im Ghaffori \\ English Department, College of Education for Humanities, Tikrit University, Tikrit, Iraq
}

\begin{abstract}
Non-verbal politeness is an important feature that characterizes human communication. Through this type of communication one can find a high degree of sophistication and civility in the language of the body, as this type of language can say and express more than language itself. Thus, there should be a use of certain cues to express courtesy and politeness such as: facial expression, eye contact, gestures, posture, and proxemics. This study aims at explaining the role of the different forms of nonverbal politeness in Prophetic Sunnah and the British etiquette books in particular, then analyzing these texts within the eclectic model of this study, highlighting points of similarity and difference between the two cultures. It is hypothesized that the two cultures display different orientations to the ways of acting non-verbally. The model adopted in this study is Martin and Nakayama (2010) with reference to Andersen (1999), Poyatos (2002) and Koneru (2008) within the framework of Brown and Levinson's model of politeness and in accordance with Hofstede's (2001) cultural values. The main conclusions of the current study are: (i) Nonverbal politeness almost goes hand in hand with other forms of verbal politeness. (ii) Non-verbal politeness is employed differently in both the Prophetic Sunnah and English etiquette books. (iii) Islamic Sunnah as compared to English etiquette books concentrates on cordiality and maintaining positive politeness among Muslims, while English etiquette texts emphasize individuality and negative politeness.
\end{abstract}

Index Terms - Etiquette, Facial expression, Non-verbal politeness, Prophetic Sunnah, Proxemics.

\section{PRELIMINARIES}

Communication is not only expressed explicity in verbal messages, but it also includes implicit messages, which are expressed through non-verbal behaviours, such as proxemics, gestures, postures, eye contact, facial expressions, kinesics, and paralinguistics. Those give salient cues, additional information and meaning, and can be marked as polite or impolite over and above verbal communication. There must be rules in order to organize communication. These rules which organize and regulate the human relationships and their communication have come to be known as 'etiquette'. The term 'etiquette' covers a great deal of the human social relationship and such notion has a relation with politeness.
Politeness is highly recommended as an umbrella for interactive social behaviour whether in English etiquette teachings or in Islamic heritage. Within the Islamic tradition, the Prophet Muhammad (PBUH) used different types of nonverbal strategies in communication in order to express high degree of politeness. The prophet Muhammad's (PBUH) use of non-verbal communication of silence, gesture, posture, eye contact, proximity, facial expression and smile shows a lot about the fact that politeness can be applicable on different levels of communication without uttering even a word. This study attempts to present an in depth analysis of the Prophet Muhammad's non-verbal politeness strategies in communication and the practical use of etiquette. On the other hand non-verbal behaviours and cues from English etiquette books will be dealt with in accordance with the same classification which will be adopted when analyzing the Prophetic Sunnah.

\section{NON-VERBAL COMMUNICATION}

Whenever people perceive information that is not written or spoken, they comprehend something that is non-verbal. Humans have the capability of receiving information besides what is written or spoken. People's facial expressions, gestures, posture, and silence are the primary sources of the nonverbal messages they receive. It is a silent language not formally taught, and which has existed before language was invented (Calero, 2005, p.1). According to theories of anthropology that long before human beings used words to communicate, our ancestors communicated with one another by using their bodies. They smiled and touched one another to indicate affection. They gritted their teeth to show anger. Modern research also confirms what the Greek historian Herodoctus observed more than 2400 years ago: 'Men trust their ears less than their eyes.' When speaker's body language is consistent with his or her words, listeners tend to believe the body language more than the words (Koneru, 2008, p.10). In this study, different forms of nonverbal communication will be dealt with from different viewpoints to cover the available selected data, starting with Andersen's category (1999), Poyatos (2002), Koneru (2008), and Martin and Nakayama (2010), who put forward the most

Journal of University of Human Development

Volume 5 No. 3(2019); DOI: 10.21928/juhd.v5n3y2019.pp156-167

Regular research paper: Published 5 August 2019

Corresponding author's e-mail: m.badea@tu.edu.iq, ayhangaffori@gmail.com

Copyright (02019 Muhammed Badea' Ahmed, Ayhan Abdul Mun'im Ghaffori. This is an open access article distributed under the Creative

Commons Attribution License (CC BY-NC-ND 4.0) 
coverable category of nonverbal communication. These forms are:

1) facial expression, according to Anderson, facial expression is part of kinesics. For him, faces are the most expressive part of bodies. One can interpret much meaning from a human face caught in a moment of expression. The universality of a core group of facial expressions are: happiness, sadness, fear, anger, and disgust (Andersen, 1999, p.35).

2) Proxemics, unlike facial expressions, the norms of personal space seem to vary considerably from culture to culture. Proxemics is the study of how people use various types of space in their everyday lives: fixed feature space, semifixed space, and informal space. It is the study of how space and distance influence communication.

3) Gestures, perhaps even more so than personal space, vary greatly from culture to culture. The consequences of this variation can be quite dramatic. Gestures are different from many other nonverbal expressions in that they are accessible to conscious awareness- they can be explained, illustrated, and taught to outsiders. (Martin and Nakayama,2010, p.276).

4) Eye contact is included in proxemics because it regulates interpersonal distance. Direct eye contact shortens the distance between two people, whereas less eye contact increases the distance. Eye contact communicates meanings about respect and status and often regulates turn-taking. Patterns of eye contact vary from culture to culture. In many societies, avoiding eye contact communicates respect and deference, although this may vary from context to context (ibid, p.270).

5) Posture is another nonverbal clue that the speaker must bear in mind while communicating. Posture is the way the speaker conducts himself when he faces listeners. It may provide some insight into whether the speaker is really interested in communicating successfully with the listener, or whether the speaker has determination and confidence too (Koneru,2008, p.11). These forms of non-verbal communication can work within the framework of politeness. Politeness not only can be seen in the form of verbal but also in non-verbal communication. Body gestures, eye contact, touching behaviour such as handshakes, holding hands, kissing (cheek and hand) and other non-verbal cues can show polite or impolite behaviour. (Elen, 2001, p.iv). The role of non-verbal expressions seems to be essential in determining politeness. Research conducted by Mehrabian (in Goman,2008, p.26 \& Bowden, 2010, p.6-7), reveals that only 7 percent of communication is determined by the use of words, 38 percent is based on the tone of voice, and 55 percent based on facial expressions, gestures, posture, and other forms of nonverbal communication. In the context of face-to-face communication, nonverbal expressions usually go along with verbal language. It can be interpreted to mean that the effect on the nonverbal aspects of politeness is very large. Non-verbal communication forms can work in similar way to face threatening, maintaining or saving acts. For example a sharp eye gaze could represent a threat to face while a smile may save it.

Brown and Levinson's theory relies on two basic notions: negative face and positive face. (Brown and Levinson, 1987). Brown and Levinson (1987, 1978) outline four types of politeness strategies that sum up human politeness behavior. These are: bald on record, positive politeness, negative politeness, and off-record-indirect strategy. 1)The bald onrecord strategy does nothing to minimize threats to the hearer's "face" 2)The positive politeness strategy shows that the speaker recognize that his hearer has a desire to be respected. 3)The negative politeness strategy also recognizes the hearer's negative face. 4)Off-record indirect strategies take some of the pressure off of the speaker. Within different cultures different forms of politeness can be signaled by etiquette, good manners or polite behaviour. These are the code that signals verbal, physical, gestural and even more primitive modes of interaction. It is the formal rules of polite behaviour in society or in a particular group (Al-Samarra'i, 2015, p.58).

\section{CULTURAL VALUES}

Culture affects and governs all facets of life by influencing values, attitudes and behaviours of a society. Values are invisible until they become evident in behavior, but culture manifests itself in visible elements too. (Hofstede,2001, p.28). Hofstede identified four dimensions in national cultures. These dimensions are:

1) Uncertainty avoidance which refers to a predominant tendency within a culture and not to all the individuals within that culture. A high score, however, indicates that the tendency is for members of this culture to have higher levels of anxiety when faced with uncertainty (Carbonell \& Rising, 2006, p.5).

2) Power Distance, Mulder (2009, p.3) says that it refers to the measure of inequality that exists- and is accepted - by people with and without power. A high PD score indicates that a high power distance can be observed in society (culture). A low score represents a low power distance. Here equality can be perceived and this can mainly be traced back to European countries.

3) Individualism vs. collectivism, Individualism within the Hofstede Cultural Dimensions refers to the strength of the mutual ties between individuals within a certain community. A high score represents 'loose' (lack of interpersonal) connections and little sharing of responsibility. (ibid. p.4).

4) Masculinity vs. Femininity, within the Hofstede Cultural Dimensions, masculinity refers to how much a society complies with its values and traditional male and female roles. For men the emphasis is on performance and success whereas for women the emphasis is on modesty, sensitivity and the quality of life. In high scores men are masculine (tough, strong and assertive) and women are feminine (submissive, subservient and kind).

\section{METHODOLOGY}

Before embarking on the procedure of data collection and 
analysis, it is important to give some explanation about the two types of data within the Prophetic Sunnah and etiquette books. The next two sections shed light on what is meant by these types of data.

\section{A. Prophetic Sunnah}

The Arabic word Sunnah lexically means "road" or "practice." In the language of the Prophet (PBUH) and the Companions it denotes the whole of licit [lawful] practices followed in the Religion, particularly the pristine path of Prophets, whether pertaining to belief, religious and social practice, or ethics generally speaking. The definition of Sunnah as used by the scholars of hadith is "What has been passed down from the prophet Muhammad (PBUH) of his statements, actions, approvals, manners, physical characteristics and biography regardless of whether it was before he was sent as a prophet or afterwards." The Sunnah, or the behavior of the prophet Muhammad (PBUH) is divided into three categories: 1) the statements and sayings of the prophet Muhammad (Sunnah qawliyah), 2) Muhammad's actions (Sunnah fi'liyah), and 3) Muhammad's approval of or silence toward practices he has knowledge of (Sunnah taqririyah).

\section{B. Etiquette Texts}

As the present study is concerned with the nonverbal politeness in etiquette books, thirty texts are chosen from British etiquette books. The selected data are concerned generally with nonverbal forms of politeness, and especially with etiquette. The rules the British follow in their daily life can be seen in their behaviours. For the British, etiquette is a way of behaviour, showing courtesy and being considerate and thoughtful to others, possessing social skills in which they don't impose upon others or make others feel uncomfortable. In order to express courtesy and politeness, people tend to use Kinesics, gestures, postures, silence, smiles and proxemics. These forms of nonverbal politeness are intentionally chosen from British etiquette books to be dealt with.

\section{DATA COLLECTION}

After surveying the two books of the British etiquette: The Gentlemen's Book of Etiquette and Manual of Politeness by Cecil Hartley (2012), and The Ladies' Book of Etiquette, and Manual by Florence Hartley (2011), and the main collections of Hadiths: Al-Bukhari's, Muslim's, Abu Dawood's, Al-Nisa'i's , and Al- Tirmidhi's, a selection of fifteen etiquette texts and fifteen Prophetic Hadiths is made respectively. Martin and Nakayama's (2010) model of nonverbal communication, with reference to Andersen (1999), Poyatos (2002) and Koneru (2008) is adopted to analyze the selected texts. The selected texts will be analyzed in accordance to Hofstede's (2001) cultural values within the framework of politeness strategies stated by Brown \& Levinson (1987).

\section{DATA ANALYSIS}

The analysis of the selected data will be conducted within the framework of the adopted eclectic model mentioned above. It is performed in a number of steps covering the elements of the model: proxemics, facial expressions, gestures, eye contact and posture respectively. The English data, which is concerned with elements of the model, will be analyzed first then followed by the Arabic data for each element of non-verbal communication within the model of analysis respectively. The English texts will be numbered successively taking the numbers 1,2 , 3, etc., while the Arabic texts will take the same numbers but with different orientation as they will be bold, italicized and underlined to set them apart from those of the English texts. The analysis tries to show how these etiquette teachings and Prophetic Sunnah can be incorporated in the model highlighting the politeness strategies which these teachings enhance and showing the cultural values behind them.

Figure (1)

The Adopted Model of Analysis

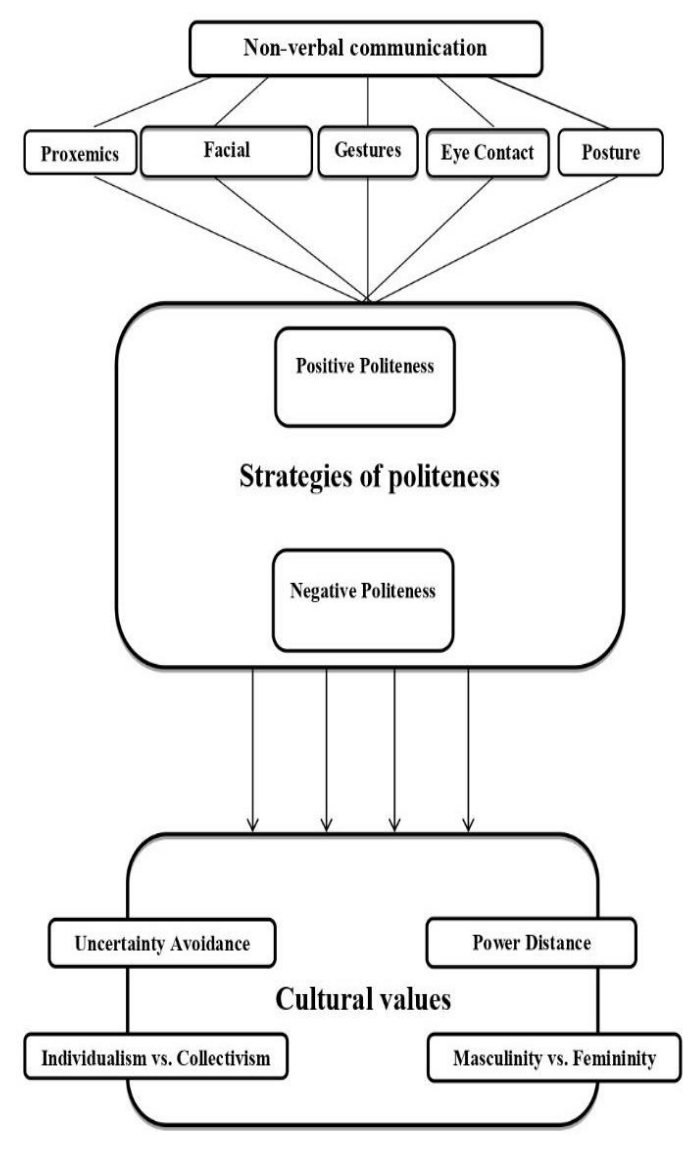

\section{1) Proxemics}

\section{English Data}

Hall (1968, p.87) argues that different cultures have different expectations of what is socially acceptable in regard to proxemics.

It is not just a passive endeavor; the British actively construct their environments to create safe spaces in an attempt to affect how they feel and whether they invite or discourage social interaction with their fellow participants. In Britain people tend to stand quite far apart when shaking hands and therefore they do so with their bodies sloping forward (Case, 2016, p.4).

So, concerning proxemics, the British like to have certain rules: 
1. If you have but one lady with you, take the seat opposite to her, unless she invites you to sit beside her, in which case accept her offer (Hartley, 2012, p.46).

2. Never sit beside a lady upon a sofa, or on a chair very near her own, unless she invites you to do so (ibid, p.52).

3. Do not exceed it crossing this invisible side, or you'll seem to invade the personal space, which can cause dislike or even uncomfort (Hartley, 2011, p.90).

Proxemics in Western cultures can differ according to the relationship:

a. The distance between British speakers (strangers) is $45 \mathrm{~cm}-50 \mathrm{~cm}$ and it can change after they know each other; and this depends on familiarity among the participants in general (Sahib, 2011, p.41).

b. Concerning gender, the distance when a man communicates with a woman is $55 \mathrm{~cm}-60 \mathrm{~cm}$ and it can change if they know each other. The distance between man and woman who are couples is much closer (Sahib, 2011, p.41).

When it comes to hugging as a signal of proxemics, it is preferable to say hello without hugging unless they are very close friends who have not met for a long time. But sometimes even neglecting the rules of etiquette is considered inappropriate and that is exactly what happened when an innocent hug made headlines around the world in 2009 when America's first lady, Michelle Obama, broke royal protocol on a visit to Britain by hugging the Queen (Thompson, 2017, p.6).

The absolute rule with strangers in the UK is "avoid absolutely all bodily contact". Generally, being too close to someone is considered almost as bad as touching. The taboo against unnecessary proximity also extends to the roads, where driving or stopping at a distance which is normal in some countries can get an aggressive reaction in the UK (Case, 2016, p.5).

\section{Strategies of politeness}

The above mentioned non-verbal cues or etiquette teachings can go hand in hand with negative politeness strategies in maintaining negative face wants to have freedom, being unhindered, given the fair amount of personal space and having due respect. This exactly what the British show in their way of keeping the distance between each other by keeping away about an arm's length. They believe that a person has the right to act freely and to have hislher taboo distance respected. According to the British culture keeping a too close distance especially with strangers can be interpreted as a threat to the rituals of avoidance' (Brown and Levinson,1987, p.129). Yet this close distance can signal intimacy between couples or mother and child, for example. It also confirms that the relationship is friendly and expresses group reciprocity by keeping the distance closer than usual. According to Brown and Levinson (ibid, 1992, p.76), factors such as social power, social distance and rating of imposition, which regulate politeness, affect the seriousness of FTA and define the form of politeness to be used in a given situation. The social distance is a combination of the psychological factors such as status, age, sex, or degree of intimacy that decide the overall degree of respectfulness (Thomas, 1995, p.124). In the same sense, proxemics is decided according to factor of sex which can show the degree of intimacy and respect.

\section{Cultural values \\ Power Distance}

The British culture can be categorized as a high power distance culture. Keeping away for accepted distance can safe other's independency and to respect histher rights of enjoying his her personal space. The British tend to keep a safe distance when communicate with others.

\section{Uncertainty Avoidance}

The British culture can be seen as a high uncertainty avoidance culture. Avoidance is clear in the area of proxemics. To respect other's need to be within an accepted distance from others is obvious, since they tend to be risk-averse. High scoring cultures avoid uncertain situations through control (rules and orders, which can be interpreted into etiquette) (Mulder, 2009, p.5). The British follow the rules of proxemics in order to show a high degree of respect to others' personal space.

\section{Individualism vs. Collectivism}

The British culture can be categorized as an individualist culture. As individuals, they, especially ladies, prefer to enjoy their personal space and to be away from any unusual proxemics. The British prefer to respect privacy, since they are attentive to the distance between each other.

\section{Masculinity vs. Femininity}

The British culture can be considered as a femininity culture according to the given text. Women's needs should be taken into consideration in the field of proxemics. Women should have the freedom to decide the accepted distance others' stand or sit near them. It is also noticed that a too close distance between the same gender is not accepted, for example friends, it is rare to see friends stand or sit near each other too closely because this is inappropriate. But it is accepted in the case of different genders, for example boylgirlfriend; it is normal to violate the taboo distance between them.

\section{Arabic Data}

\section{Nonverbal Cues- Proxemics}

Kuliyva and Salah (2018) say that in most cases, the nonverbal language of people from other cultures is different from the one that is familiar to Muslims, and that is exactly the case as the Prophet (PBUH) states showing the accepted space between people of the same gender:

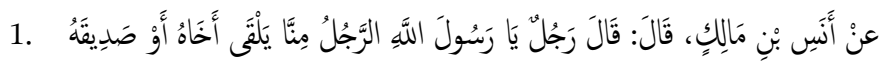

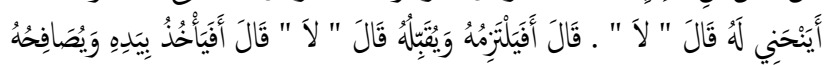

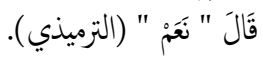

Narrated Anas bin Malik: that a man said: "O Messenger of Allah! When a man among us meets his brother or his friend should he bow to him?" He said: "No." The man continued: "Should he embrace him and kiss him?" He said: "No." He said: "Should he take his hand and shake it?" He said: "Yes." 
For Muslims the accepted distance between the participants can be one arm's length, as the Prophet (PBUH) advises Muslims to shake hands when meeting each other, and shaking hands can be performed at an arm's length.

The prophet Muhammad (PBUH) emphasizes the proper distance between a Muslim and his brother in more than one Hadith, even in prayer, as it is an essential and daily corner in the lives of Muslims:

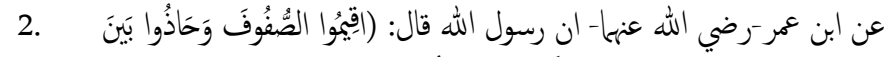

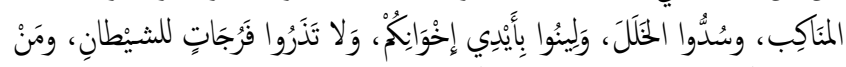

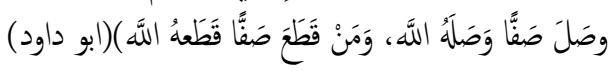

Narrated from Abu Hurairah that the Messenger of Allah

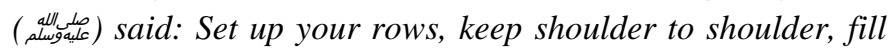
the gaps, be considerate to each other, do not leave any room to Satan. He who completes the row, Allah bless him and he who cuts off the row, will not get Allah's mercy.

The Prophetic Hadith shows exactly how distance among Muslims can be explained. For Muslims the situation is completely different during prayer. They have to leave no distance between them when praying, and because of this closeness among Muslims in Mosque, the close distance is reflected in their daily communication and becomes usual and accepted among the same gender.

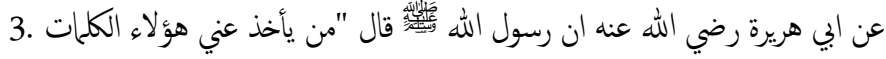

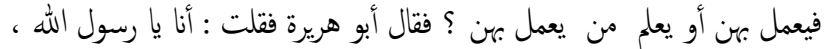

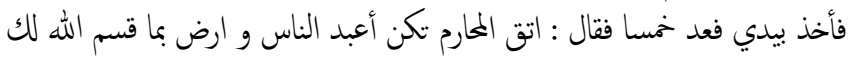

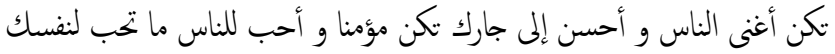

$$
\begin{aligned}
& \text { تكن مسلما و لا تكثر الضحك ، فإن كثرة الضحك تمثيت القلب مأب (الترميذي) }
\end{aligned}
$$

Narrated from Abu Hurairah that the Messenger of Allah (2) said: "Who will take these statements from me, so that he may act upon them, or teach one who will act upon them?" So Abu Hurairah said: "I said: 'I shall O Messenger of Allah!' So he (") (a) took my hand and enumerated five (things), he said: "Be on guard against the unlawful and you shall be the most worshiping among the people, be satisfied with what Allah has alloted for you and you shall be the richest of the people, be kind to your neighbor and you shall be a believer, love for the people what you love for yourself and you shall be a Muslim. And do not laugh too much, for indeed increased laughter kills the heart."

The Prophet expresses fair intimacy with his companions. No distance can be seen when he (PBUH) is among them, and this is clear when he took Abu Huraira's hand to count for good worship. This closeness can explain the domain of proxemics among Muslims.

The Prophet (PBUH) encourages closeness among Muslims, as mentioned in prayer. He (PBUH) believes that Muslims together are like the bricks of a wall, enhancing each other:

$$
\begin{aligned}
& \text { عن ابي موسى الاشعري رضي الله عنه قال: قال رسول الله - صلى الله عليه }
\end{aligned}
$$

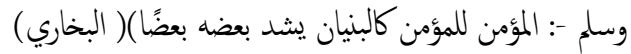

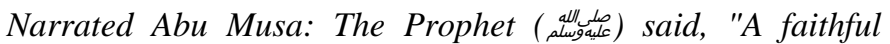
believer to a faithful believer is like the bricks of a wall, enforcing each other."

Concerning the distance which should be maintained between individuals of different genders, Muslims in general try to maintain a very ample distance between different genders and both men and women have to maintain that distance.

\section{Strategies of politeness}

The positive politeness strategy is clearly used in Arab Islamic culture as people do not mind being close to show respect and intimacy among them. On the other hand, negative politeness strategy is also encouraged by them when different genders are engaged in communication.

\section{Cultural values}

\section{Power Distance}

Arab Islamic culture can be categorized as a low uncertainty avoidance culture, since members are willing to take risks and appreciate flexibility and informality in the area of proxemics. They do not mind being close to each other and that can be seen clearly in prayer. Concerning other situations, Muslims show flexibility, and distance between them can be close depending on the nature of the relationship.

\section{Uncertainty Avoidance}

The Arab Islamic culture can be seen as a low uncertainty avoidance culture. Muslims do not avoid to be near to each other. The cues of proxemics-nearness can exactly explain the dimension of uncertainty avoidance.

\section{Individualism vs. Collectivism}

Arab Islamic culture can be shown as having a culture with a low score (more collectivism), since there is a strong group cohesion. They tend to be closer to each other, yet keeping the hierarchical structure of the society.

\section{Masculinity vs. Femininity}

Concerning the masculinity and femininity, Muslims show a great deal of respect concerning women. It is inappropriate to be close to a strange woman. Showing intimacy and closeness between couples- husband and wife- in public is also considered unacceptable. The distance between members of different genders should be within the range of formality.

\section{2) Facial Expression}

\section{English Data}

Facial expressions are among the most universal forms of body language. Thampson $(2017$, p.3) argues that the expressions used to convey fear, anger, sadness, and happiness are similar throughout the world.

The British are always careful about showing any emotions on their faces- stiff upper lip- is traditionally used to describe an attribute of British people in remaining resolute and unemotional, and since these emotions are universal, they have certain rules to follow. Concerning the point of anger, they insist on the following: 
1. Learn to restrain anger (Hartley,2012, p.112).

Showing a pleasant face and cheerful facial expression is also an important thing to express politeness:

2. The advantage and necessity of cheerfulness and intelligent intercourse with the world is strongly recommended (ibid).

3. Polite persons are necessarily obliging. A smile is always on their lips, an earnestness in their countenance, when we ask a favor of them (Hartley,2011, p.185).

\section{Strategies of politeness}

In Britain "politeness" is typically used to describe negative politeness, which is presumed to be "a good thing." (Fukushima,2003, p.27). The British control their emotions and rarely share them through their facial expressions, and this can be done using negative politeness. On the other hand, the cheerfulness is a positive act in general and performing such an act may pave the road for positivity and ease of communication. It signals friendliness and encourages positive interactions. People are drawn more to people whose faces look happy.

\section{Cultural Values \\ Power Distance}

Here the British culture can be seen as a low power distance culture. The British make it a rule to show pleasant facial expression to show an acceptable degree of politeness. Smiling is performed regardless of the power distance parameter, i.e., it does not show the practice of power among participants. Also, controlling negative facial expressions when communicating is preferable.

\section{Uncertainty Avoidance}

The British can be considered as a low uncertainty avoidance culture. Cheerfulness can make others feel friendly and the attitude of acceptance is spread over the communication process. Drawing a smile on the face when communicating needs no uncertainty avoidance measures among the participants.

\section{Individualism vs. Collectivism}

The British, in this particular behaviour, can be categorized as a collectivist culture. Showing a polite reactions can be seen as a care attitudes to others' feelings and the need for acceptance among others.

\section{Masculinity vs. Femininity}

The British can be seen as an average culture concerning masculinity and femininity. Both are advised to show a pleasant facial expression, control anger, and smiling. The British culture is a $\mathrm{s}(\mathrm{he})$ culture.

\section{Facial expression}

\section{Arabic Data}

One form of the realization of politeness is based on the use of polite facial expression. A listener will feel uncomfortable or offended by the facial features shown by the speaker (Chuchu,2014, p.643).
When speaking with relatives (family)or other Muslim brothers, Islam advocates showing cheerfulness through facial expression.

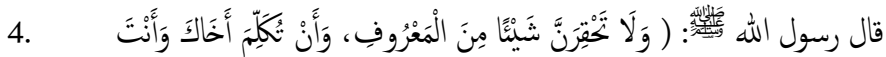

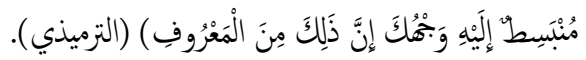

"Do not belittle even the smallest act of kindness, even if it were no more than meeting your brother with a smiling and cheerful face"

Giving much smiling is recommended in Islam as the prophet Muhammad (PBUH) did (Sahib,2011, p.41).

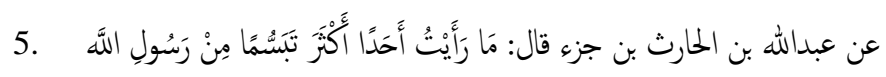

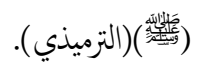

"I never came across a person who smiled as much as Prophet Muhammad (PBUH)"

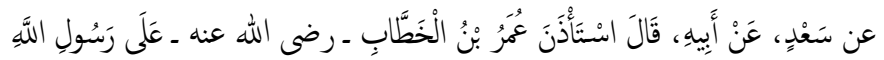

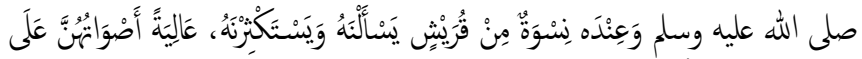

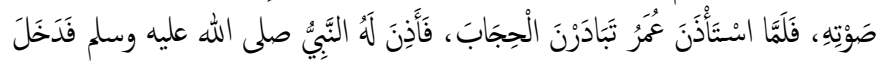

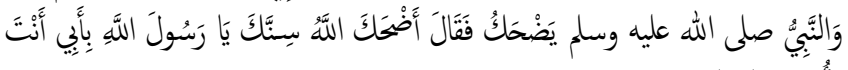

$$
\begin{aligned}
& \text { وَأَِّّي.( البخاري). }
\end{aligned}
$$

Narrated Sa'd: 'Umar bin Al-Khattab asked permission of Allah's Messenger (allughtc) to see him while some Quraishi women were sitting with him and they were asking him to give them more financial support while raising their voices over the voice of the Prophet. When 'Umar asked permission to enter,

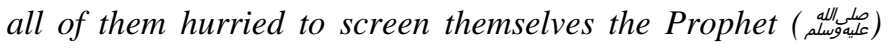
admitted 'Umar and he entered, while the Prophet (م) مughalc) was smiling. 'Umar said, "May Allah always keep you smiling, $O$

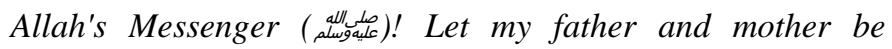
sacrificed for you!"

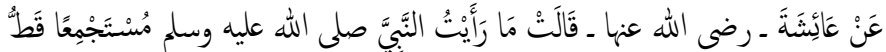

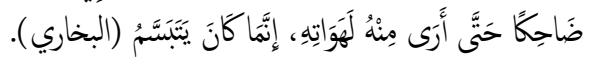

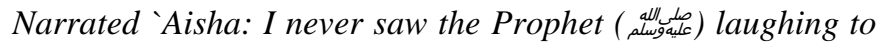
an extent that one could see his palate, but he always used to smile only.

The prophet Muhammad (PBUH) insists on showing cheerfulness when dealing with others. This is obvious in the expressions reflected by him (PBUH).

When something happens that the prophet does not approve of or does like, it is shown on his face.

6.

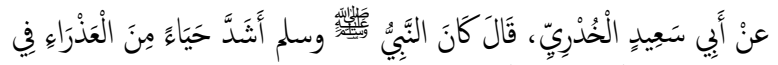

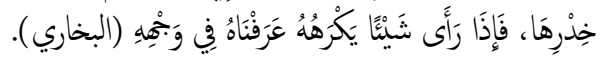

Narrated Abu Sa id Al-Khudri: The Prophet (aلdingatc) was more shy than a virgin in her separate room. And if he saw a thing which he disliked, we would recognize that (feeling) in his face. 


\section{Strategies of politeness}

Brown and Levinson (1992, p.129) suggest that being optimistic is one of the strategies to meet the requirement of positive politeness. In the same sense the Prophet Muhammad (PBUH) used to be optimistic and to show a smile whenever he met others. He (PBUH) wants to show others that being soft and gentle with others brings nothing apart from goodness and ease of communication. Arab Islamic culture tends to spread positivity and cheerfulness during communication. The ease of communication is clear. They show pleasant facial expressions which give others a feeling of relieve and easiness.

\section{Cultural values}

\section{Power Distance}

Arab Islamic culture is scored with a low power distance, since there is no inequality in society and there is a fair amount of showing pleasant facial expressions. Muslims do not believe in the inequality among members. Muslims seek friendliness, intimacy, and warmth in communication. In the same sense, they offer a smile to express friendliness and to pave the way for a good communication.

\section{Uncertainty Avoidance}

Arab Islamic culture can be categorized as a low uncertainty avoidance culture, since they do not mind showing a kind of accepted facial expressions concerning pleasure, unpleasant, dislike and sadness as long as these facial expressions are within the limit of politeness.

\section{Individualism vs. Collectivism}

The Islamic culture can be seen as a collectivist culture. Muslims look for the group unity. They tend to have close relationships with others and engage in different social communications.

\section{Masculinity vs. Femininity}

The Islamic culture can be seen as a s(he) culture. showing a cheerful face is encouraged to both men and women but with the same gender. Women are not supposed to show smiles when dealing with strange men. A pleasant face should be restricted only when communicating with the same gender. It is not recommended to show a cheerful face to the opposite gender, instead, both should lower their gaze.

\section{3) Gestures}

\section{English Data}

\section{Nonverbal cues- Gestures}

While some gesture can be universally recognized and have a clear interpretation in one culture, another culture may not have any designation, or have a completely opposite meaning. In the modern world mandatory element of any meeting and farewell is shaking hands. It also has a lot of information about the feelings, intentions and relations. This information is sent, for example, through the position of hands, as well as the intensity or duration of a handshake (Chuchu,2014, p.687).

Case(2016, p.3) argues that unless one is feeling particularly passionate about seeing someone, a UK handshake tends to be quite short, with around three small shakes up and then down. There are also times when it can be shorter, maybe even just one shake up and down, for example when meeting a large group of people or when shaking hands again at the end of a meeting. Generally, too short is better than too long. In fact, people shaking hands for too long and/ or too far up and down is a very common sign of a character's lack of social skills in British comedies.

For them, shaking hands should be offered for all, regardless of the gender, age, or situation. Shaking hands should be done again when departing the place.

Handshakes are light -- not firm (Hartley, 2012, p.115).

Shake the hand just two or three times before letting go. Keep it brief (ibid).

Another issue when shaking hands, the British tend to shake hands only when meeting someone for the first time or meeting again after a long time, often while saying "Pleased to meet you" or "(Long time no see). It's so nice to see you again". In other situations such as a second meeting the next day, just briefly raising your eyebrows and/ or one palm in a "Hi" gesture is usually more appropriate. The same is true in more informal situations and/ or when meeting a large group of people, where shaking hands might seem "too much" and/ or a waste of time (Case, 2016, p.4).

Never offer to shake hands with a lady; she will, if she wishes you to do so, offer her hand to you, and it is an impertinence for you to do so first (Hartley, 2012, p.44).

Women should extend their hand to men first (ibid, p.116). It is preferable for the British to let ladies offer a handshake first.

The British tend to avoid any other bodily contact during handshakes, with the left hand not being used at all. For example, a hug and handshake at the same time is very rare in Britain. In the UK, grabbing the other person's forearm with your other hand while shaking hands means something like "It's a real honor to meet you" or "I am forever in your debt", and tends to only be used in situations like someone being your hero. Holding the other person's shoulder when you shake hands means something like "Are you holding up okay?", for example after their partner has died, and so is also very rare (Case, 2016, p.5).

On the other hand, gestures can be expressed in different forms, for example, a "head nod":

If meeting someone in the street, a 'head nod' is as good as a smile for a passing greeting (Hartley, 2012, p.41).

Pointing with a finger or a hand is considered rude for the British:

Never point. It is excessively ill-bred (Hartley, 2011, p.90).

\section{Strategies of politeness}

The positive politeness strategy is used expressively by the British when they shake hands, or nodding for each other. Conditional positive politeness is the norm when shaking hands with women- it is inappropriate to offer shaking hands with a lady - it is appropriate only if she offers first. 


\section{Cultural values \\ Power Distance}

The British culture can be categorized as high power distance culture. They never offer a handshake to a lady unless she offers first.

\section{Uncertainty Avoidance}

The British culture can be seen as a high uncertainty avoidance culture. The avoidance concerning gender is clear, men avoid offer a handshake first. The women should take the role first.

\section{Individualism vs. Collectivism}

The British culture can be considered as an individualistic culture. Women as individuals, have the right to enjoy their personal and social space. At the same time their enjoyment should not be invaded by others by offering a handshake from men unless they offer first. The choice is theirs.

\section{Masculinity vs. Femininity}

The British culture can be categorized as a feminist culture. women take the role to decide a handshake or not.

\section{Nonverbal cues- Gestures}

\section{Arabic Data}

According to Hassan \&Mohd (2005, p.86) there is a touch categorized as decent touch. The touch is made for example when we meet someone or separate with someone. Such as shaking hands or hugging. In Islam, a person (Muslim) is encouraged to shake hands to get forgiven and strengthen silaturahim (tighten bond among Muslims).

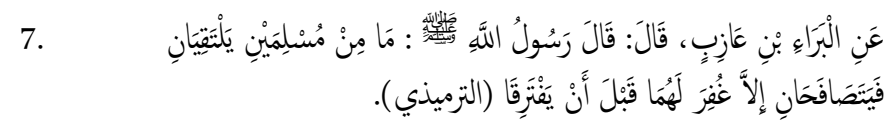

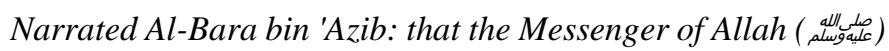
said: "No two Muslims meet each other and shake hands, except that Allah forgives them before they part."

Concerning shaking hands, one thing should be taken into consideration which is gender. The prophet (PBUH) refrained from shaking hands with women:

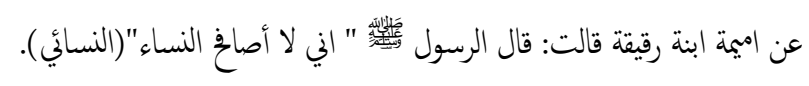

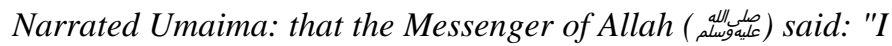
do not shake hands with women"

Muslims are advised to follow certain rules in shaking hands.

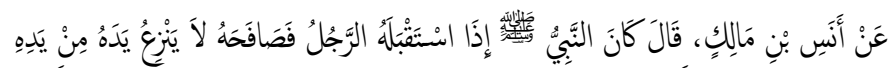

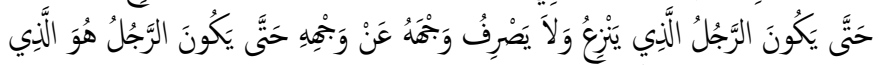

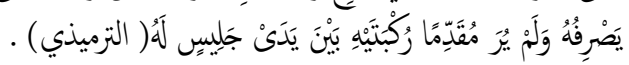

Anas bin Malik narrated: "When the Prophet (PBUH) would receive a man to shake hands with him, he would not remove his hand until he [the man]removed his, and he would not turn his face away from his face until the man turned and he would not be seen advancing his knees before one sitting with him."

The duration of a handshake according to the prophet (PBUH) is important in reflecting the sense of honoring.

Muslims observe the importance of using the right hand as the prophet Muhammad peace be upon him usually did :.

8.

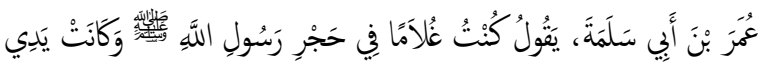

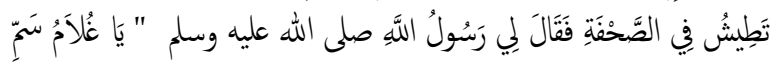

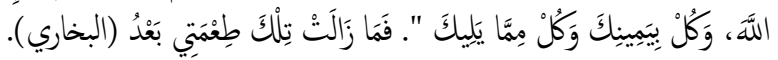

Narrated 'Umar bin Abi Salama: I was a boy under the care of

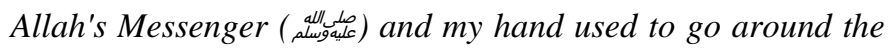

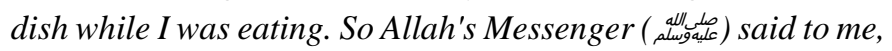
'O boy! Mention the Name of Allah and eat with your right hand, and eat of the dish what is nearer to you." Since then I have applied those instructions when eating.

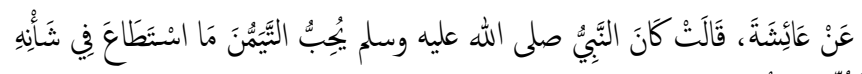

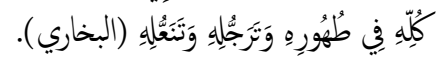

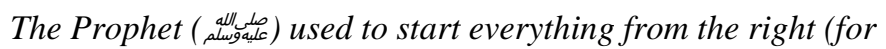
good things) whenever it was possible in all his affairs; for example: in washing, combing or wearing shoes.

The prophet (PBUH) pointed with his fore and middle fingers:

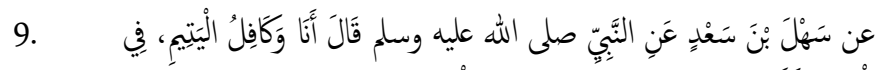

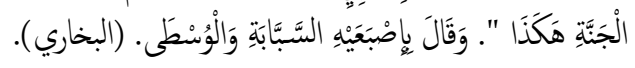

Narrated Sahl bin Sa'd: The Prophet (aلdughale) said, "I and the person who looks after an orphan and provides for him, will be in Paradise like this," putting his index and middle fingers together.

\section{Strategies of politeness}

The positive politeness strategy in the case of Arab Islamic culture is encouraged. Muslims are advised to shake hands in almost all the situations expect with women. In the case of different genders, negative politeness is preferable as Muslims should refrain from shaking hands with women, thus keeping the taboo space that women should enjoy in the Muslim society. On the other hand, showing kindness and sympathy using gesture is also recommended. Muslims encouraged to use gesture respectively as the prophet (PBUH) did.

\section{Cultural values \\ Power Distance}

Arab Islamic culture is scored with a low power distance, since they shake hands with kids, old, and young. They prefer to use different gestures to reflect kindness, cordiality and strong brotherhood. But it would be a high power distance concerning the opposite gender. Men should never shake hands with women who are not related to them, and this may give women a special locus in the social area that they are protected from any forbidden touch with men. 


\section{Uncertainty Avoidance}

Arab Islamic culture can be categorized as a low uncertainty avoidance culture. They enjoy using extra movements-gestureto show informal attitudes and intimacy especially among the same gender. The matter is different with the opposite gender.

\section{Individualism vs. Collectivism}

Arab Islamic culture can be described as a collectivism culture. Muslims like to shake hands, pointing, gesturing freely in a polite way.

\section{Masculinity vs. Femininity}

The Arab Islamic culture can be seen as a masculinity culture concerning gesture. Men should respect women's personal space and not to shake hands with them. On the other hand, Muslims use gesture respectively in different situations.

\section{4) Eye contact}

\section{English Data}

\section{Nonverbal cues- Eye contact}

Eyes are used to show some values such as love, gratitude, joy and response (Chuchu, 2014, p.685). When it comes to eye contact, the British are somewhere in the middle of the international range, with avoiding eye contact and too much eye contact being equally negative.

Always look at the person you are communicating with in order to show that you are interested in them and to hold their attention (Hartley, 2012, p.101).

Looking away may encourage the other person to look or search harder to make eye contact with you (ibid).

Avoiding eye contact may also convey disinterest (ibid).

All the texts found in the books of British etiquette encourage the British to give a good eye contact with the listener to show interest, care, and to send a message that one is attentive.

For the British it is not preferable to stare at people, it shows rudeness: Staring at people, spitting, looking back after they pass, saluting people across the street, all these are considered rude (Well,2009, p.47) .

\section{Strategies of politeness}

Eye contact, as far as the British culture is concerned can have two different social values. It can reflect a positive politeness strategy when used to keep the conversational line of contact and to assure the partner that one is following and paying attention to what is going on in the conversation. The British prefer to give others their due attention through eye contact; this is on the one hand. On the other hand keeping long eye contact or gazing at others could be rude or an act of trespassing the personal space that one has. So, such an act should be avoided as a kind of negative politeness strategy.

\section{Cultural values \\ Power Distance}

The British culture can be seen as a low power distance culture. They prefer to give a suitable eye contact when communicate and to let others feel that they get their full attentions.

\section{Uncertainty Avoidance}

The British is described as a low uncertainty avoidance culture. British people do not mind eye contact in their communication, even among opposite genders.

\section{Individualism vs. Collectivism}

The British culture can be seen as a collectivism culture. Mutual eye contact can be done by both gender. It is preferable for them to contact by eyes and to show full attentions to others.

\section{Masculinity vs. Femininity}

Concerning masculinity and femininity, the British Perform the same eye contact regardless of gender. They do not mind contact by eyes.

\section{Arabic Data}

\section{Nonverbal cues- Eye contact}

Eyes show particular affection to your participants, eye contact is a sign of confidence and attentiveness. We tend to assume that if someone looks away while we are talking to, they are disinterested and are looking for someone else to talk to ( Thompson,2017, p.6). The view that reflects the feelings of gratitude, joy and response will have a positive impact on the listener and thus can make communication effective.

For Muslims, dealing with eyes contact differs somehow from what there is in the British culture. Gender plays a great role concerning eye contact. Muslims are ordered to avoid a second look at a woman; a first look is allowed if it happens accidently:

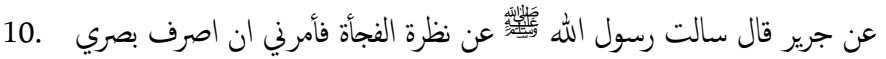

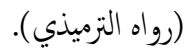

Jarir narrated: he said: I asked the messenger of Allah about an accidental glance (on a woman), he said: "turn away your gaze (from her).

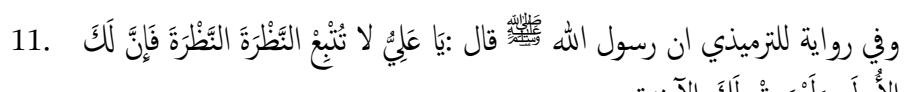

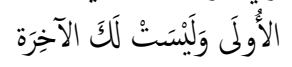

" O Ali, do not follow the first look (at a woman) with another. There is no blame on you for the first but you have no right to the second".

In accordance to Islamic principles, males and females are expected to lower their gaze and avoid sustained eye contact with each other. This is considered respectful and observant of the partition between genders. Even in Glorious Qur'an it is mentioned that both men and women should lower their gaze:

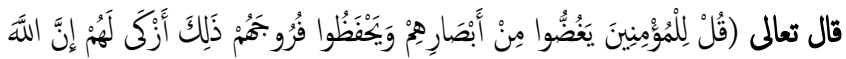

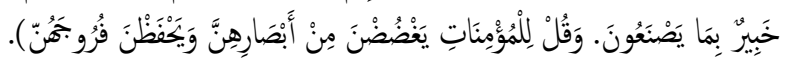

«Tell the believing men to reduce [some] of their vision and guard their private parts. That is purer for them. Indeed, Allah is Acquainted with what they do( Alnur30)» 
Concerning the etiquette of the road, the prophet (PBUH) insists on the importance of lowering the gaze as passersby pass:

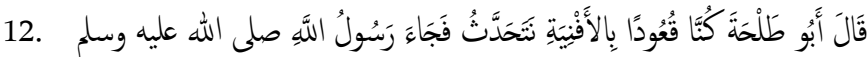

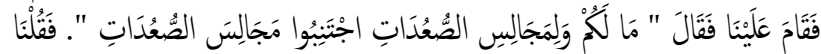

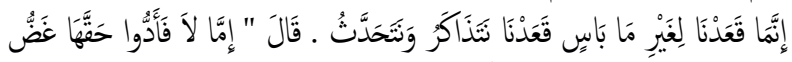

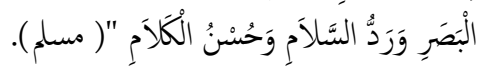

While we were sitting in front of the houses and talking

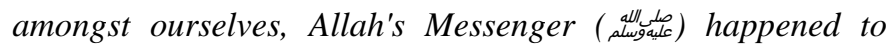
come there. He stood by us and said: What about you and your meetings on the paths? Avoid these meetings on the paths. We said: We were sitting here without (any intention of doing harm to the passers-by); we are sitting to discuss matters and to hold conversation amongst ourselves. Thereupon he said: If there is no help (for you but to sit on these paths), then give the paths their rights and these are lowering of the gaze, exchanging of greetings and good conversation.

\section{Strategies of politeness}

The negative politeness strategy gives the person the right to act freely, so, Muslims always try to keep their gaze lowered when communicating. They should not gaze at a woman, or a passerby in the street. On other hand, they give their full attention using eye contact respectively when communicating with the same gender and this part of positive politeness.

\section{Cultural values \\ Power Distance}

Arab Islamic culture can be seen as a high power distance culture. The idea is comprehended in the concept of inequality which is represented in the idea of separation between genders. Each individual has the right to be respected and to enjoy his her personal space "zone" and this separation preserves the rights of the society members maintaining their independence, especially women.

\section{Uncertainty Avoidance}

Arabic Islamic culture can be seen as a high uncertainty avoidance, since they avoid extra eye contact between men and women.

\section{Individualism vs. Collectivism}

Arab Islamic culture can be considered as an individualist culture, since they prefer to respect individual's right of enjoying personal space and keeping taboo distance.

\section{Masculinity vs. femininity}

Concerning Masculinity and femininity, Muslims show a great respect to the opposite gender. They do not gaze at women, and if that happens accidently, they should not follow the first with a second look. Both genders are ordered to lower the gaze.

\section{5) Posture}

\section{English Data}

\section{Nonverbal cues- Posture}

All people, not only the British, are interested in ensuring that their interactions in the process of communication are successful. Case(2016, p.6) mentions that the usual modern British standing and sitting style is most notable for how slack it is. For example, putting the hands in the pockets, sitting with the spine bent, sitting on the edge of a desk as helshe gives a presentation or putting one knee forward as helshe stands so that one hip drops and the body leans to one side are all unlikely to be even noticed in the UK. For the British, it is important to take care of the way people move, sit, walk or even eat:

Avoid restless movements either with the hands, or feet; to sit perfectly quiet, without stiffness, easily, yet at the same time almost motionless, is one of the surest proofs of high-breeding (Hartley,2011, p.144).

The way one stands can tell a lot about him/her. The British avoid any unappropriated posture especially those performed by ladies:

To stand with the arms a-kimbo, the hands on the hips, or with the arms crossed, while conversing, is exceedingly unladylike. (ibid).

The British express a great deal of respect when they communicate with older persons:

Never remain seated, whilst a person older than yourself is standing before you, talking to you (ibid).

\section{Strategies of politeness}

The British are keen on and they usually emphasize negative politeness in maintaining proper conduct and keeping the personal space of individuals. This lies within the negative politeness strategies. By resorting to negative politeness the British, always try to perform acceptable posture when they sit, eat, walk and stand.

\section{Cultural values}

\section{Power Distance}

The British can be considered as a high power distance culture since inequality can be perceived. They try not to adopt any posture that makes others feel uncomfortable. as mentioned in the given texts, an accepted posture is far from restless movements, stiffness, or with the arms crossed . Such an act may prevent the communicator from indulging in a successful communication, and that is because inequality attention might be shown by one or both communicators. So, the British prefer to show a great deal of respect when communicating; they take care of the way they sit, stand, walk, and even lie. The British consider posture as a cue to express politeness.

\section{Uncertainty Avoidance}

The British can be seen as a high uncertainty avoidance culture. They tend to show a high degree of respect and abiding by discipline concerning the domain of posture. They avoid any kind of unusual postures, like to stand with the arms a-kimbo, or being seated while talking to older people. 


\section{Individualism vs. Collectivism}

The British culture can be categorized as an individualist culture. They tend to respect the individual's right by keeping away from any unexpected posture or postures which threaten others' personal space.

\section{Masculinity vs. Femininity}

The British culture can be shown as an average culture. Both men and women are supposed to follow the rules of etiquette which insist on performing certain and expected postures when communicating with others.

\section{Arabic Data}

\section{Nonverbal cues- Posture}

Muslims pay a great attention to the way they sit, the way they stand, and even to the way they eat. The prophet Muhammad (PBUH) performs different postures in different situations. Concerning the way Muslims should follow when they eat, the prophet (PBUH) said:

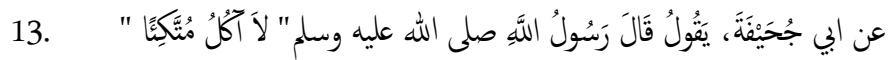

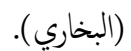

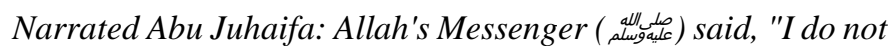
take my meals while leaning (against something).

What is meant by leaning is any manner of sitting in which one is too comfortable and relaxed in a way which may express showing off or self-effacement which is refused by Muslims as the Islamic teaching cues insist on showing humility and modesty.

The prophet (PBUH) advised Muslims to change their position when getting angry:

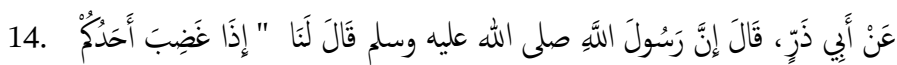

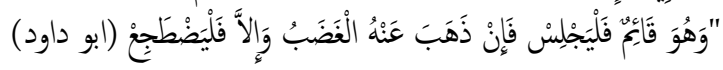

Narrated Abu Dharr: The Messenger of Allah (⿻ل1) (ع) Said to us: When one of you becomes angry while standing, he should sit down. If the anger leaves him, well and good; otherwise he should lie down.

Concerning posture, the Prophet's (PBUH) used to show great kindness and care for little children. He used to carry his granddaughter while he stood up praying and put her down when he prostrated:

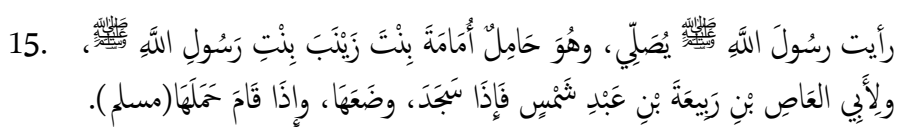

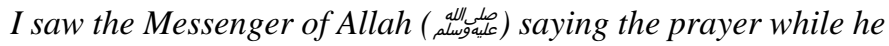
was carrying Umama, daughter of Zainab, daughter of the

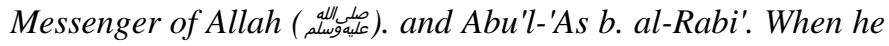
stood up, he took her up and when he prostrated he put her down.

The way of good manner of walking is also clear in the Glories Qur'an:

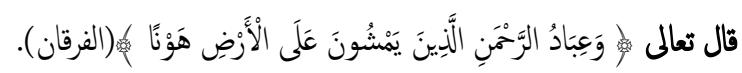

«And the servants of the Most Merciful are those who walk upon the earth easily, and when the ignorant address them [harshly], they say [words of] peace(63)» [Al-Furqan: 63]

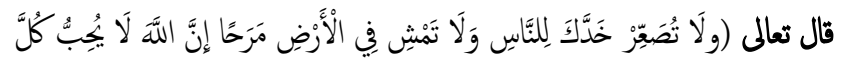

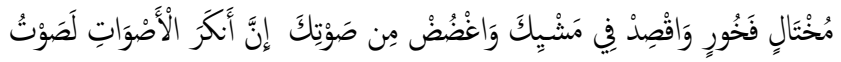

$$
\begin{aligned}
& \text { الْحَمِيرِ (لقمان:19). }
\end{aligned}
$$

«And be moderate in your pace and lower your voice; indeed, the most disagreeable of sounds is the voice of donkeys."(Luqman, 19)»

When meeting others, it is not acceptable to bow as it is explained in Hadith number (1) page ( 8)

\section{Strategies of politeness}

Positive politeness strategy is emphasized by Muslims since they perform different postures within the frame of politeness. One should not bow to others as this act might put him in a lower status compared with others, and this act of bowing is exclusively practiced in prayers. So maintaining equality among Muslims is enhanced via this positive politeness strategy of keeping Muslims as one community within the domain of (we). Also it is reflected in the posture of eating. Eating while leaning can be shown as a show off act which should be far away from Muslims and their morals, they are encouraged to show humility and modesty.

\section{Cultural values}

\section{Power Distance}

The Arab Islamic culture can be seen as a low power distance culture. They prefer to encourage equality among members and to show respect to their rights.

\section{Uncertainty Avoidance}

The Arab Islamic culture can be categorized as a low uncertainty avoidance culture. Being modest in the way one walks and sits especially while eating is emphasized in these Islamic teachings. They express simplicity in the way they sit and eat. Humility is the most prominent characteristic that a Muslim should maintain which is reflected in their postures in different situation.

\section{Individualism vs. Collectivism}

The Arab Islamic culture can be considered as a collectivist culture. Muslims seek unity and oneness. They tend to maintain in-group behaviour and to save the group's members cohesion.

\section{Masculinity vs. Femininity}

The Arab Islamic culture can be seen as an average culture. Both men and women are supposed to perform posture politely.

\section{CONCLUSIONS}

The main conclusions of the current study are:

I. The realization of politeness non-verbally in the British culture and the Arab Islamic culture has almost the same forms. Both cultures realize non-verbal politeness in face 
expression, eye contact, gestures, posture, and proxemics but in different meanings and attitudes.

II. Non-verbal politeness almost goes hand in hand with other forms of verbal politeness.

III. Islamic Sunnah as compared to English etiquette books concentrates on cordiality and maintaining positive politeness among Muslims, while English etiquette texts emphasize individuality and negative politeness.

IV. Arab Islamic culture keeps a clear distinction between males and females as far as non-verbal communication is concerned highlighting the fact both genders can behave intimately when the deal with members of the same gender, while there are certain restrictions on their dealing with the other gender.

V. Arab Islamic culture tends to employ a closer distance in communicating with the members of the same gender unlike the English culture where such a distance is more restricted.

VI. The Islamic religious practice is reflected in the social behaviour of the Muslims as they try to apply the Islamic teachings in almost all fields of life. So, we can say that non-verbal communication in the Muslim community is religiously based, unlike that of the British which does not have this dimension.

\section{REFERENCES}

Al-Samarrai, M. B. (2015). English- Christian and Arabic- Islamic Etiquette Teachings. Lambert: Academic Publishing.

Andersen, P. (1999). Nonverbal Communication: Forms and Functions. Mayfield: Mountain View Company.

Bowden, M. (2010). Winning Body Language: Control the Conversation, Command Attention, and Convey the Right Message- Without Saying a Word. NY: Mc Graw Hill Professional.

Brown, P. \& Levinson, S. (1987). Politeness: Some Universals in Language Usage. Cambridge: Cambridge University Press.

Brown, P. and Levinson, S. (1992). 'Left' and 'right' in Tenejapa: Investigating a linguistic and conceptual gap. In L. de León and S.C. Levinson (eds.), Space in Mesoamerican languages (pp. 590-611). Berlin: Akademie Verlag.

Bousfield, D. (2008). Impoliteness in Interaction. Amsterdam: John Benjamin Publishing.

Calero, H. (2005). The Power of Nonverbal Communication. Los Angles: Silver Lake Publishing.

Caston, Jan. (1984) . Cultural Awareness Teaching Techniques / Jan Gaston. -Vermont, p. 90 .

Chuchu, F. \& Mahali, N. (2014). International Conference on Social Sciences and Humanities: Politeness in Advertisements Based On NonVerbal Cues. 8-10 September 2014- Istanbul, Turkey.

Davis, D. (2014). How to Design a Life Worth Smiling About: Developing Success in Business and in Life. McGraw Hill Professional.

Ekman, Paul. (2007) Emotions revealed. New York: Holt.

Elen, G. (2001). A Critique of Politeness Theories. Manchester: St. Jerome Publishing.

Fukushima, S. (2003). Requests and Culture: Politeness in British English and Japanese. Germany: Peter Long AG.

Gabriele, J. (2009). Negative politeness disarms superiors, encouraging them to grant your requests. Polar Politeness Psychology Today . Published on September 01, 2000 - last reviewed on January 14

Gladstone, G. (2002). "When you're smiling, does the whole world smile for you?". Australasian Psychiatry. 10 (2): 144-146

Hartley, C. (2012). The Gentlemen's Book of Etiquette and Manual of Politeness. Boston: G.W. Cottrell Publisher.

Hartley, F. (2011). The Ladies' Book of Etiquette, and Manual. Boston: G.W. Cottrell, Publisher.
Hoque M., Morency, L., \& Picard , R. (2011) Are You Friendly or Just Polite? - Analysis of Smiles in Spontaneous Face-to-Face Interactions. In: D’Mello S., Graesser A., Schuller B., Martin JC. (ed.) Affective Computing and Intelligent Interaction. ACII 2011. Lecture Notes in Computer Science, vol. 6974. Springer, Berlin, Heidelberg

Hassan ,A. \&Mohd, A. (2005). SeniBercakap-cakapdanBerbual-bual. Kuala Lumpur: PTS Publications \& Distributors.

Hofstede, G.(1994). Cultures and Organizations - Intercultural Cooperation and its importance. California: Sage Publications, Inc.

Hofstede, G. (2001). Cultures Consequences. California: Sage Publications, Inc.

Hofstede, G. \& Hofstede, G. J. (2005). Cultures and Organizations: Software of the Mind. McGraw Hill.

Koneru, A. (2008). Professional Communication. New Delhi: Taha Graw Hill.

Leathers, Dale \& Eaves, Michael. (2015). Successful Nonverbal Communication: Principles And Applications. Place of publication not identified: Routledge.

Martin, J. \& Nakayama, T. (2010). Intercultural Communication in Contexts. New York: Mc Graw Hill Companies.

Novinger, T. (2001). Intercultural communication: a practical guide. Austin, TX: University of Texas Press.

Ogiermann, E. (2009) An Apologizing in Negative and Positive Politeness Culture. Amsterdam: John Benjamin Publishing,.

Pease, A. \& Pease, B. (2004). The Definitive Book of Body Language. Australia: Pease International.

Eckert, P. \& Mc Connel-Ginet, S. (2003). Language and Gender. Cambridge: Cambridge University Press.

Poyatos, F. (2002). Nonverbal Communication Across Disciplines: VII Paralanguage, Kinesics, Silence, Personal and Environmental Interaction. Amsterdam: John Benjamins Publishing Company.

Rising, B. \& Carbonell, A. (2006). Culture and Communication. Georgia: College of Management.

Sahib, M. (2011). Western and Islamic Cultures on the Use of Non-Verbal Polite Expressions (A Cross-Cultural Understanding). Sulesana: V. 6, N. 2.

Thomas, J. (1995). Meaning in Interaction. Edinburgh: Longman.

Well, S. (2009). How to Behave: A Pocket Manual of Etiquette and Correct Personal Habits. Boston: The Floating Press.

Marina, R. (2015). International Conference "Linguistic and Cultural Studies: Traditions and Innovations", LKTI 2015, 9-11 November Tomsk, Russia Politeness Strategy in Everyday Communication.

Yule, G.( 1996). Pragmatics. Oxford: Oxford University Press.

\section{Internet References}

https://search.yahoo.com/yhs/search?hspart=iba\&hsimp=yhs1\&type=46nt_8021_CHW_IQ\&p=sunnah.com.

https://www.islamreligion.com/articles/4155/value-of-time/

Kuliyeva N., Salah, R. (Unpublished Paper on the Website http://elib.bsu.by/bitstream/1/Kuliyeva ,N. \&Salah, R. Etiquette of Nonverbal Communication in Britain and Iraq.

Mulder, P. (2009). Cultural Dimensions By Geert Hofstede. https://www.toolshero.com/communication-skills/hofstedecultural-dimensions/

Thompson, S. (2017). Cultural Differences in Body Language to be Aware of / https://virtualspeech.com/blog/cultural-differences-in-bodylanguage/.

Case, A. (2016). British Body Language. An Article on the Websitehttps://www.usingenglish.com/articles/british-body-language.html.

$$
\begin{aligned}
& \text { المصادر العربية } \\
& \text { القران الكريم. } \\
& \text { النسائي, احمد (1991) سنن النسائي الكبرى. بـيروت: دار الكتب العلمية. }
\end{aligned}
$$

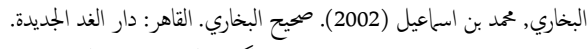

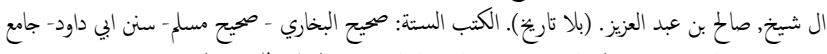

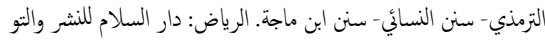

